\title{
Organization of foreign trade in the Krasnoyarsk Territory: assessing possibilities for IT application
}

\author{
Ruban Olga Viktorovna \\ Siberian Federal University, \\ Krasnoyarsk, Russian Federation \\ Baguzova Larisa Valentinovna \\ Siberian Federal University, \\ Krasnoyarsk, Russian Federation
}

\author{
Voloshin Andrey Vladimirovich \\ Siberian Federal University, \\ Krasnoyarsk, Russian Federation \\ Suslova Julia Yurievna \\ Siberian Federal University, \\ Krasnoyarsk, Russian Federation
}

\author{
Saraskina Lyubov Evgenievna \\ Siberian Federal University, \\ Krasnoyarsk, Russian Federation \\ Kravtsov Dmitry Ivanovich \\ Siberian Federal University, \\ Krasnoyarsk, Russian Federation
}

\begin{abstract}
Regional climatic factors determine the socioeconomic conditions for the external relations organization of economic entities, whose activities play the key role in the Krasnoyarsk Territory economy. Foreign trade organization analysis allowed establishing trends in its development, identifying main counterparties, and revealing the features of partnerships in export-import operations implementation and a contract conclusion. As a result of the research, the authors established the reasons for the change in the cost of deliveries to the region and the products export, import- export commodity structure, the mechanism for mutual trade with other states through electronic bidding.

Problems of foreign trade organizing are summarized by the authors and the prospects for regional enterprises cooperation with partners from far and near abroad are highlighted, taking into account the experts` views.
\end{abstract}

Keywords: the Krasnoyarsk Territory economy, foreign trade turnover, import- export structure, foreign trade

\section{INTRODUCTION}

Regional features determine the industrial complex formation and the Krasnoyarsk Territory economy due to its geographical location.

The competitive advantages of the region are composed by the use of electricity generated in the region territory and natural resources availability. The specific weight of the region's industrial production is $4 \%$ in the industry of Russia, and in the East Siberian Economic Region - 40\%. In the structure of industrial production, the production of fuel and energy minerals is 26.3\%; metallurgical production and production of finished metal products $-39.2 \%$; production and distribution of electricity, gas and water $-11.2 \%$ [1].

Industrial companies form a significant share of regional gross domestic product. At the same time, enterprises focused on the export of raw materials account for the largest share. Therefore, the current state of foreign trade of the Krasnoyarsk Territory is characterized by a predominant share of export activity in foreign trade turnover and a surplus.
An innovative approach to the foreign trade entities activities organizing determines the automated procurement systems usage. This circumstance is confirmed by the increase in the electronic transactions number, and herewith large industrial companies create their own corporate electronic platforms.

\section{LITERATURE REVIEW AND RESEARCH METHODS}

The study is based on a specific field of economic relations related to the development of foreign trade on the bases of modern scientific and technological achievements in the information and communication interactions environment.

Based on the data of scientific studies and individual studies of foreign scientists $[2,3,4]$, it should be noted that currently there are relatively few scientific works in the field of assessing the relationship and impact of customs payments on the state of the country's economic potential. Interaction with customs authorities is necessary for participants in foreign economic activity, and Russia's accession to the WTO facilitated the simplification of trade procedures [5,6], which affected the development of electronic commerce. The application of various methods and methods includes modern information systems, platforms, electronic trading platforms, as well as the capabilities of outsourcing companies $[7,8]$. Therefore, there is a need for further research on the possibilities of electronic technology in organizing foreign trade

The materials presented on the official websites of departments, which are the subjects of foreign trade infrastructure, made it possible to identify the features of the foreign economic activity of the Krasnoyarsk Territory enterprises. Great importance for development trends identifying in the commodity circulation sector has the information presented in the materials of the respective ministries and the chamber of commerce.

As a result of the published data analysis of the Siberian Customs Administration reports, we obtained the product 
by $5.9 \%$. At the same time $94.1 \%$ of foreign trade turnover

structure of import and export with partners from near and far abroad states, conducted an analysis of tenders in terms of large industrial companies activities organizing on electronic trading platforms of various kinds.

The Russian Federation legislation indicates that the foreign economic activity of enterprises consists of foreign trade, investment and other cooperation, including industrial cooperation in the international exchange of products, goods, information, work, services, intellectual activity results, and the rights to them. The work is devoted to the organization and development directions of foreign trade in the region.

\section{RESULTS}

The development of foreign trade is initiated by the processes of globalization, integration, and digitalization. The Krasnoyarsk Territory innovation policy is aimed at sustainable economic growth ensuring, where new technologies are of paramount importance.

Foreign economic activity is characterized by technological ties with production, material and technical capabilities, entrepreneurial criteria, among which the main one is efficiency. Ensuring a stable economic and financial situation of enterprises is possible through the use of modern information systems and platforms. The economic situation predetermines the digital technologies usage as a vector for the regional trade development.

The Krasnoyarsk Territory trade relations are determined by the regional economy structural features. As a result of the analysis, it was found that the share of mineral mining organizations is $21 \%$, manufacturing industry - $29 \%$ of the total turnover of economic entities (Fig. 1).

\begin{tabular}{l|r} 
& $2018 \mathrm{r}$. \\
\hline Agriculture & 56856,2 \\
\hline Manufacturin & 1206566,1 \\
\hline Mining & 865869,6 \\
\hline Building & 153619,3 \\
\hline Electricity Su| & 247873 \\
\hline Wholesale ar & 889396,2 \\
\hline Transportatic & 271182,1 \\
\hline Other & 497374,3 \\
\hline & 4035117,5
\end{tabular}

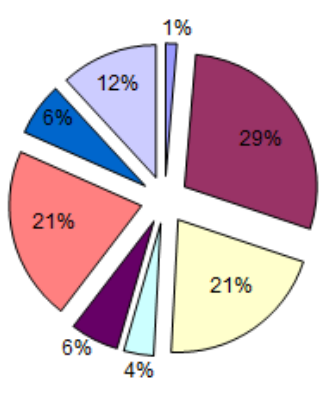

口Agriculture

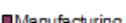

口Mining

口Building

Electricity Supply

aWholes ale and retail trade

- Trans portation and storsge

口Othes

Fig. 1. The Krasnoyarsk Territory organizations turnover by the type of economic activity in 2018 [9]

In 2018 the industrial production index was 106.4\%; the average indicator in Russia was $102.9 \%$. [10]. 558 participants in foreign economic activity took part in export operations at the customs department, and 653 took part in import operations in the reporting year. These enterprises have state registration in the Krasnoyarsk Territory.

At present time the growth tendency in the foreign trade turnover of the Krasnoyarsk Territory continues. In 2018, this indicator increased by 2154.1 million US dollars or by $31.7 \%$ compared to the previous year (Fig. 2). The foreign trade balance amounted to 4768.1 million US dollars and increased takes place with non-CIS countries.

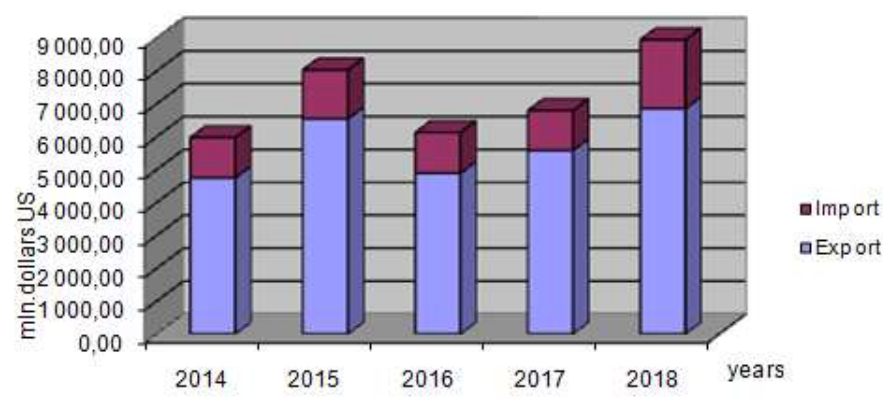

Fig. 2. The Krasnoyarsk Territory foreign trade turnover dynamics

With an increase in export volume by $22.8 \%$, its share is reduced from $82.2 \%$ to $76.7 \%$ in the analyzed period, the share on imports of non-CIS countries increased to $84.4 \%$.

Foreign trade turnover was provided by partners from nonCIS countries by $94.1 \%$, trade with neighboring countries was amounted to $5.9 \%$ of the value of goods turnover.

Export-import operations were carried out with counterparties from 116 countries. At the same time, the Netherlands accounted for the maximum share in foreign economic cooperation - 24.3\%, China - 19.6\%, Germany $10.1 \%$ (Fig. 3).

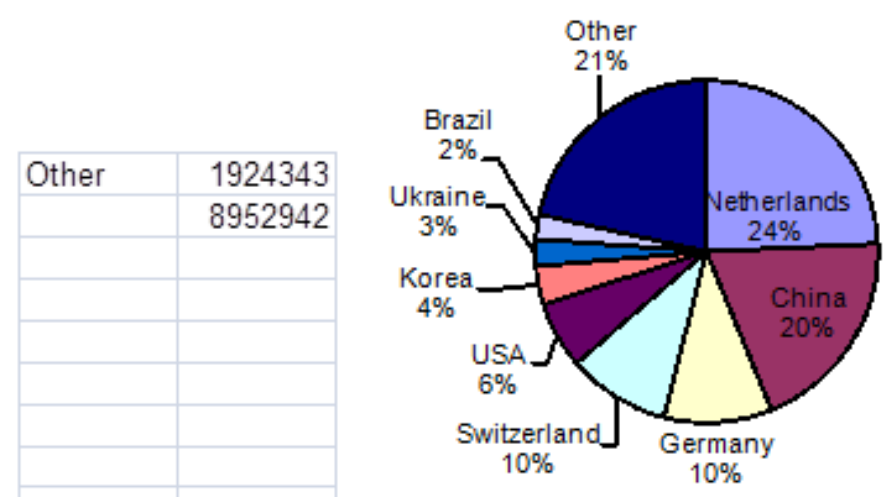

Fig. 3. The main partner-countries of the enterprises of the Krasnoyarsk Territory in 2018 [4]

In 2018 goods were imported with places of origin of which 100 countries were marked, and last year - 95 countries. The largest share accounted for the import of products from the United States - 22.1\%. The value of imports from this country was increased by 4.4 times. The share of goods imported from China was amounted to $17.7 \%$, an increase is $15.3 \%$.

The foreign trade imports volume was increased in 1.7 times and amounted to 2092379 thousand US dollars in the reporting period, the physical volume of imported goods was increased by $7.7 \%$. Import from non-CIS countries was increased in 1.8 times or by 789.2 million US dollars, from CIS countries - by $38.3 \%$ compared with 2017 .

This economic phenomenon is due to the 2.1 times increase in the import of engineering products, which is 
Every year there is an increase in electronic bidders, users $50.7 \%$; the 1.5 times increase is in chemical products import, the share of which is $34 \%$ of imported products value (Fig. 4).

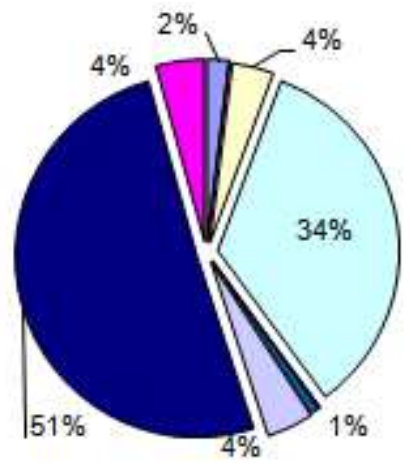

Fig. 4. Import product structure in 2018

\begin{tabular}{|l|r|r|}
\cline { 2 - 3 } chemical products, rub ber & 482554,6 & 715847,1 \\
\cline { 2 - 3 } leather raw materials, furs & 22,8 & 2397,8 \\
\hline wood and pulp and paper pr & 765289,4 & 2459,7 \\
\hline textiles, textile products an & 1309,0 & 14507,9 \\
\hline metals and products from tr & 4421066,5 & 86353,1 \\
\hline engineering products & 142927,5 & 1061739,0 \\
\hline other goods & 247667,1 & 90208,8 \\
\hline
\end{tabular}

Fig. 5. Export product structure in 2018

In the indicated period the largest share in export was accounted for metals and products from them $64 \%$ out of the total volume of exported products (Fig. 5). The value of their export is amounted to 4421.1 million US dollars and was increased by $19.4 \%$ mainly due to an increase in the supply of nickel and copper to non-CIS countries; export of mineral products was increased by $32.6 \%$ compared to the last year.

In the analyzed period of time, exports were carried out to 93 countries; the highest growth rate of its value volume is in trade with Germany (2.8 times), China (1.4 times), and Switzerland (14 times). In the reporting year, export to neighboring countries was increased in 1.6 times and amounted to 200.6 million US dollars; the share of these countries was amounted to $2.9 \%$ of the value of export. The main exporter of forest products is China. Last year, $86.5 \%$ of lumber and round wood from the total volume of exported forest products outside the region were exported to this country.

The Krasnoyarsk Territory foreign trade turnover in mutual trade in 2018 was amounted to 179.4 million US dollars and increased in 1.6 times comparing to the last year. This type of foreign economic activity was carried out with the EAEU member states, which include Kazakhstan: the share in trade turnover is $68.8 \%$; Belarus (21.7\%), Armenia (5\%), and Kyrgyzstan (4.5\%).

Enterprises, participants in foreign economic activity, carry out various organizational, economic, industrial, commercial functions taking into account a specific strategy, forms and methods of work in foreign markets. of information platforms of federal, commercial, and corporate electronic trading floors. At the same time, the participation of industrial companies in the operation of electronic trading floors consists in carrying out procurement procedures for the selection of a supplier for the provision of a range of logistics operator services for the delivery of material and technical resources. To do this, a request is made for prices when purchasing material and technical resources, as well as a request for proposals for construction, energy supply, radio communications, and the selection of a contractor for the project.

The studied industrial enterprises hold open tenders for the services provision expertise of technical solutions adopted in design works implementation, fixed assets repair, equipment, instead of worn one, replacement [11,12].

Nowadays the problems of electronic technologies usage in foreign economic activity are discussed at all administrative levels.

At a meeting of the Council of Chambers of Commerce supervisors, the importance of digital technologies development was noted, saying that the latter determine the possibilities for creating advanced information platforms for the development of entrepreneurship. In organizing their activities, business entities must use various interactions formats that allow them to receive legal, marketing, and consulting services on-line [13].

The introduction of new ways in the Krasnoyarsk customs work, electronic technologies contributes to the customs administration improvement aimed at convenient services creating and foreign economic activity organization simplifying. In 2017, automatic registration of declarations for exported goods was introduced, that is, without customs specialists' participation, which amounted to $56 \%$, that is $16 \%$ higher than expected.

At present time the Federal Customs Service departments in Russia are being reformed based on the creation unified regional electronic customs and electronic declaration centers. The location of the Siberian electronic customs is indicated in the city of Krasnoyarsk [14].

It is planned that the entire electronic declaration array of the Siberian Customs Administration will be concentrated here, including the electronic processing of customs operations. Work on customs declaration in electronic form will begin from the moment of the Siberian customs post creation in the electronic customs structure [15].

\section{DISCUSSION}

In order to expand external relations, the European Union countries have a common portal for procurement organizing [13]. Departmental sites reflect the conditions of business and export activities in English. However, detailed information on tenders is available only in the language of the country. According to experts, despite of open foreign countries Internet sites, where official authorities and companies post the design and working documentation of projects, a range of 
relevant information on international tenders, the number of Russian enterprises is rather small.

The enterprises of the fuel and energy complex have limited opportunities for large-scale open projects for the production and shipment in electronic form due to the specifics of their structural organization. The functional system of the electronic trading platform enables the procurement of material and technical resources, as well as sales, allow providing competitive procedures, automating the offers collection from potential contractors and expanding the partnership base at the expense of foreign contractors. Taking into account oil and gas enterprises high potential, they can increase activity in the work through electronic technologies in export activities organizing. Trading procedures and customs operations are carried out online through electronic document management. Experts note the possibility of B2B technologies developing in the companies of industrial complexes in the region, and national products exporting. The country is facing a transition to a new, innovative model of economic development [16,17,18,19].

\section{CONCLUSION}

Large industrial companies form economic relations with suppliers using their own automated systems and electronic trading platforms, which create certain conditions for resources acquisition providing production units.

In the international aspect a business model that includes digital technology allows regional industrialists participating in foreign market transactions more actively. At the government level it is emphasized that the need to use digitalization is a global trend and the main direction for business climate improving. The use of the electronic form of import and export operations, and foreign economic services is estimated by experts as a perspective field for regional enterprises external relations quality improving. Foreign electronic commerce is a set of economic relations of foreign counterparties regarding the sale of goods, products, services through electronic technologies on a mutually beneficial basis. Its development is facilitated by the information platforms improvement, governing actions legislation in this area, and electronic declaration centers creation.

It can be concluded that the use of information platforms that ensure the development of electronic business attract participants in foreign economic activity. The foreign trade operations of commodity circulation in the international sector confirm the effectiveness of business relations and the conclusion of contracts through electronic technologies. The indicated advantages predetermine promising areas of export and import organization that contribute to economic growth and improve the quality of foreign trade.

\section{REFERENCES}

[1] The concept of industrial policy of the Krasnoyarsk Territory until 2030 [Electronic resource]. Available at: http://www.krskstate.ru/promtorg/strateg.
[2] S. De Galbert, "A Year of Sanctions against Russia - Now What? A European Assessment of the Outcome and Future of Russia Sanctions", Center for Strategic and International Studies, 2015 [Electronic resource]. Available at: https://www.csis.org/analysis/year-sanctionsagainst-russia $\% \mathrm{E} 2 \% 80 \% 94$ now-what.

[3] D. Gros and F. Mustilli, "The Economic Impact of Sanctions against Russia: Much ado about very little", Centre for European Policy Studies, 2015 [Electronic resource]. Available at: https://www.ceps.eu/publications/economic-impact-sanctions-againstrussia-much-ado-about-very-little.

[4] M. Szczepański, "Economic impact on the EU of sanctions over Ukraine conflict", European Parliament, 2015 [Electronic resource]. Available at: http://www.europarl.europa.eu/thinktank/en/document.html?referenc $\mathrm{e}=$ EPRS_BRI(2015)569020.

[5] A. Grainger, "The WTO trade facilitation agreement: Consulting the private sector", Journal of World Trade, 2014, 48 (6), pp. 1167-1188 [Electronic resource]. Available http://eprints.nottingham.ac.uk/28471/1/TRAD\%2048 -6_Andrew\%20GRAINGER.pdf (Accessed: 10 March 2018).

[6] J. Pauwelyn, "How to win a world trade organization dispute based on non-world trade organization law?", Journal of World Trade, 2003, vol. 37, no. 6, pp. 997-1030.

[7] J. J. Suslova, L. T. Smolentseva, E. A. Nechushkina, and L. V. Ivanova, "Integration Processes in Trade Sector", Mediterranean Journal of Social Sciences, 2015, vol. 6, no. 2, S.4, pp. 145-149. ISSN:2039-9340.

[8] L. V. Baguzova, J. J. Suslova, N. V. Ananeva, V. V. Kuimov, O.S. Veremeenko, "The Regional Market for the Development of Outsourcing Services", Journal of Advanced Research in Law and Economics, 2017, vol. VIII, no. 4 (26), pp. 1056-1072 [Electronic resource]. Available at: https://elibrary.ru/item.asp?id=30629164.

[9] "Federal State Statistics Service", Krasnoyarsk Regional Statistical Yearbook 2018 [Electronic resource]. Available at: https://krasstat.gks.ru/folder/30015.

[10] Portal of the Krasnoyarsk Territory, Ministry of Economy and Regional Development of the Krasnoyarsk Territory, "The main results of the socio-economic development of the region for January-December 2018" [Electronic resource]. $\quad$ Available at: http://econ.krskstate.ru/ser_kray/itog/0/id/33160.

[11] Siberian Customs Administration. Customs statistics [Electronic resource]. Available at: http://stu.customs.ru/statistic.

[12] Centralized procurement of the Nornickel Group [Electronic resource]. Available https://www.nornickel.ru/suppliers/tenders/central/?archive $=$ Y .

[13] Chamber of Commerce and Industry of the Russian Federation [Electronic resource]. Available at: https://tpprf.ru/en/vneshniesvyazy/\#analitika-po-ved.

[14] I. Galaguz, "Siberian electronic customs will appear in Krasnoyarsk", Kommersant [Electronic resource]. Available at: https://www.kommersant.ru/doc/3793064

[15] A. Kornev, "Siberian Electronic Customs started working in Krasnoyarsk", Continent Siberia Online Portal [Electronic resource]. Available at: https://ksonline.ru/354131/v-krasnoyarske

[16] V. Faltsman, M. Krakhina, "Analysis and Forecast on whether Russia will integrate into and converge with the World Economy", CONTEMPORARY EUROPE-SOVREMENNAYA EVROPA, 2018, issue 5, pp. 71-81.

[17] A. F. Linetsky and D. Ye. Kuznetsova, "Foreign Trade Relations of Russia and Its Regions with the USA under Economic Sanctions", Upravlenets-the manager, 2017, issue 5, pp. 26-33.

[18] Y. N. Zelenov, A. V. Gubareva, and K. E. Kovalenko, "Specificity of sinusoidal development of foreign economic activity in the Russian Federation", Revesta Universidad y sociedad, 2017, vol. 9, issue 5, pp. 282-284.

[19] O.G. Austvik and C. Lembo, "Eu-Russian gas trade and the short comings of international law", Journal of World Trade, 2017, V. 51, no. 4, pp. 645-674. 